\title{
Stages of Rural Transformation in the National Strategic Tourism Area of Borobudur
}

\author{
Aditha Agung PRAKOSO ${ }^{1 a}$, Eugenius PRADIPTO ${ }^{a}$, Muhammad Sani ROYCHANSYAH ${ }^{a}$ \\ ${ }^{a}$ Gadjah Mada University, Department of Architecture and Planning, 55281 Yogyakarta, Indonesia
}

\begin{abstract}
The Borobudur area has grown into a world-class tourist destination. With the existence of Borobudur, Mendut, and Pawon temples, the area was appointed as National Strategic Tourism Area (NSTA). The condition influences the villages surrounding it. Borobudur village, Wanurejo, and Candirejo have developed into alternative tourist villages. During their development, these villages have undergone several transformation stages, which are interesting for further observation. In this background, the study aims to identify the transformation stages of the tourist villages in the Borobudur area, from the beginning as a people settlement to become tourist villages, and what causes the development of these stages. This study used a multiple-case study method with diachronic time series analysis, with three village units of analysis: Borobudur, Candirejo, and Wanurejo. Therefore, it will produce the stages of the village's transformation, especially, those related to tourism activities in the Borobudur area. It is expected that the results of this research will provide tourism development guidelines at each stage of the transformation of tourism villages so that they can be the basic for proper tourism planning for the government in rural tourism, especially in the development of tourism villages in NSTA. In addition, it can also be the basic of a scientific approach in researching the development of tourist areas, especially tourism village.
\end{abstract}

Keywords: Transformation, Rural Tourism, Borobudur, Indonesia

\section{Introduction}

Changes in the meaning of cultural reserve or cultural heritage will affect the growth of the surrounding area (Karatosun and Çakar, 2017). Borobudur is an area that has been designated as a UNESCO World Heritage Site. This area has developed into a world-class tourist destination. It had even been designated as a National Strategic Tourism Area (NSTA) by the Indonesian government in 2011 and a Super Priority Tourism Destination in 2019. This area development directly influences the growth of the surrounding villages. One of them is the development of rural settlements into areas that support tourism facilities (Prakoso, Pradipto, and Roychansyah, 2020) For example, the function changing of residential houses into tourist accommodation or household-based tourism businesses are often referred to as home-based enterprises (HBEs) (Ahmed, 2017). This development does not occur instantaneously, but grows gradually and takes a long time. This process is called transformation. It is a continuous process of change, which is a response of the force to produce a new identity to survive and overcome the challenges (Dewi, 2012; Habraken, 1983; Najoan and Mandey, 2011). This change occurs due to a shift in the value of culture and social interaction of society caused by enculturation, acculturation, discussion, and cultural synthesis (Sesotyaningtyas, Pratiwi, and Setyono, 2015). The development of a rural settlement into a tourist village implies the improving the community surviving and responding to future challenges. In this case, the development of the Borobudur area is due to the growth of tourism activities centered on heritage tourism.

\footnotetext{
${ }^{1}$ Corresponding author: Aditha Agung PRAKOSO, E-mail: aditha.agung.p@mail.ugm.ac.id. Received in August, reviewed in October, published in December.
} 
As previously explained, this change occurs gradually, starting with the development of tourism activities which were initially only in the area around the temple. They spread throughout the village. In the final stage, tourism village development has become alternative tourism in the Borobudur area today. This stage occurs due to the influence of several factors, both internal and external factors. So, the villages grow as an area that mainly focuses on the economic aspect. As a result, the villages tend to minimize the physical and socio-cultural environment aspects.

This raises the research question: how did the tourism village's transformation stages in NSTA Borobudur occur? In oder to find the answer, the study aims to identify the couses of transformation stages of the tourist villages in the Borobudur area. This results may help in developing guidelines for policy planning of the government to maintain the authenticity of tourism villages, which is the value of the uniqueness and attractiveness.

As a research limitation of this study is the period of analysing the development of tourism villages in NSTA Borobudur, since the Borobudur Temple became a UNESCO Cultural Heritage site in 1991 until the pre-Covid-19 pandemic at the end of 2019.

\section{Literature Review}

Rural tourism is based on traditional agriculture and agrotourism. However, over time, the concept of rural tourism has expanded. It includes more activities, such as: village tours, water activities, conservation, cultural and educational activities, and health and culinary activities (Ahmed and Jahan 2013). Basically, tourism village activities are based on the physical environment of the rural area (Stabler 1997). Tourism villages in the management process have also undergone development. Tourism villages, in general, will be developed by local communities because they know exactly all the advantages and can explore the potential contained ( Prakoso, Pradipto, Roychansyah, and Nugraha 2020). The rural tourism development involves several parties cooperation, such as government and private sectors, usually being in business capital and human resource training. Rural areas are areas that cannot be separated from their spatial development, and a rural transformation from a residential area into a tourist area will also change the land use of the area to become more complex (Xi et al., 2015). Pamungkas and Muktiali (2015) stated that is not only about changes in spatial planning and physical geography, but also in the community's economy, social, and culture. In other words, an area will experience changes from time to time both physically and non-physically. This is influenced by the activities of the community, and the surrounding environment will change according to the needs of the people in it (Setyaningsih 2016). In the concept described by Habraken (1983), continuous changes in the area are referred to as transformation.

In the last few years, several types of research have been carried out on the area transformation, but the findings on the transformation stages have not been well explained and clearly described. Xi et al. (2015) explain rural transformation development, with the hierarchy of village land use development influenced its distancing from the core attraction. Widyastomo et al. (2015), in their article Setting Transformation and the Meaning of Residence in Sentani's Tribe Tradition, explain the cultural transformation of finding the meaning of rooms, changings of ornaments, and houses structures in traditional Sentani tribal houses in Papua province. Depari (2017), in his research on spatial transformation, found factors that affect the development process in Kauman village. Research on physical transformation arrangements was also carried out by Al-Athas (2016), regarding the changes in the shape of the road network and the special 
formation that occur on the scale of the city of Bandung. The discussion of transformations in the territorial order has been discussed by Setyaningsih (2016) regarding the transformation of tourist villages and Susanti et al. (2018) regarding the transformation of occupancy due to home base enterprises household business activities. From these various studies on the transformation, it is observed that they still limited to explaining the transformation order's scope. Therefore, it needs to be explained and enriched with the scope of the transformation stages, so that the description of architectural transformation will be more explicit and complete.

Transformation tracing can be obtained from the timeline description of tourism village development in the case unit. This tracing is to determine what the stages of the transformation look like.According to the opinion of Butler (1980); Miossec (1976); dan, van Doorn (1979) the stages of transformation can be concluded in synthesis in Table1.

Table 1. Stage of Transformation

\begin{tabular}{|l|l|l|l|}
\hline Miossec (1976) & van Doorn (1979) & Butler (1980) & Synthesis \\
\hline Early & Exploration & Exploration & Exploration \\
\hline Medium & Local Initiation & Involvement & Participation \\
\hline Develop & Institution & Development & Consolidation and \\
& & Consolidation & Expansion \\
& & Stagnation & \\
& & Rejuvination & \\
\hline
\end{tabular}

Source: Adaptation after: Butler, 1980; Miossec, 1976; van Doorn, 1979.

In a cross-analysis of transformation stages the the researcher is going to employ, with the following:

1. Exploration, is the pioneering stage of the area with the development of attractiveness and infrastructure that is still natural as it is.

2. Participation, is the stage where local communities' involvement and the development of attractions and infrastructure due to the increasing needs of tourists.

3. Consolidation and Expansion Stage, the investors are starting to involve, planning policies from the government begin until the damage could happened to the area, changing the tourism concept.

\section{Methods}

\subsection{Research Paradigm}

This study uses a rationalistic qualitative paradigm, with a descriptive construction of the object study (Vanderstoep and Johnston 2009). The theme of this research on phasing is very elaborately described with a qualitative paradigm, as Groat \& Wang (2013) explained that qualitative is objectively appropriate to understand development history and the transformation processes that have occurred. Rationalism emphasizes a comprehensive understanding through theoretical conceptualization and literature study as a benchmark for testing approaches, analysis results, and discussion of a research problem (Moleong 2005). Based on these theories, the researcher acts as the main instrument with an in-depth interview process to get the developments and changes in the area.

\subsection{Research Methods}

The in-depth theory understanding is carried out to determine this research method by examining research articles on transformation. The next stage is exploring the theoretical gap to get the difference or gap that occurs between state of the art and the empirical or phenomena that 
occur in the field, with the gap that there is no proper concept in explaining the stages of transformation of villages in the strategic national tourism area. So, this research is conducted to enrich and modify the theory of village transformation. From the description (Figure 1), it is determined that the appropriate method of this research is a multiple-case study chosen to explain and enrich the transformation theory on the theme of village transformation stages. This research will be conducted in 3 villages at NSTA Borobudur, including Borobudur, Candirejo, and Wanurejo Villages (Figure 2). These three villages were selected based on the area's development level, which was directly affected by the status of the NSTA.

The transformation elaborating process is described using chronological changes from the initial form to the current one (Habraken, 1983). The chronological description of this transformation is explained by a timeline analysis in each village (diachronic time series). In advance, the causal relationship will be calculated (logic model) and compared between villages (cross-case synthesis) to further observe the transformation stages based on the initial analysis of the theory of transformation stages (Butler, 1980; Miossec, 1976; van Doorn, 1979). Thus, the analysis of developmental stages at NSTA of Borobudur are synthesized and produce 3 stages as the basis of analysis, namely (1) exploration, (2) participation, (3) consolidation and expansion.

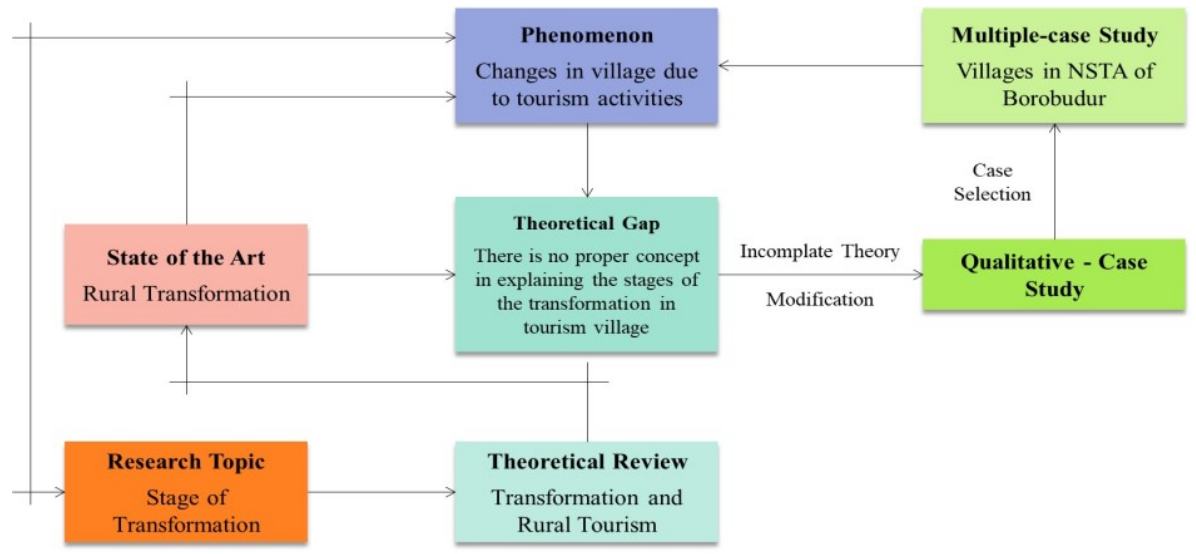

Figure 1. Research Method Identification. Source: Adopted from Yin, 2009.
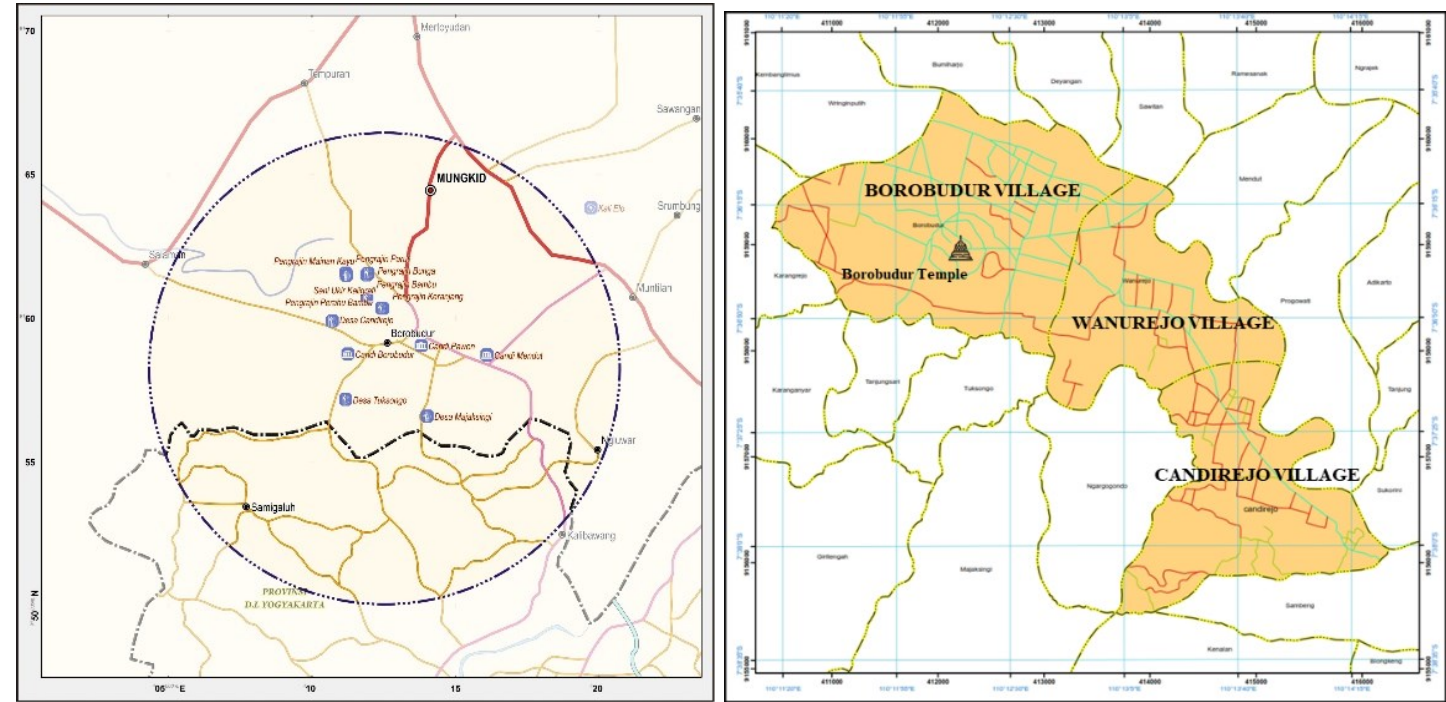

Figure 2. NSTA of Borobudur and Research Locus. Source: National Tourism Development Master Plan (RIPPARNAS) of the Indonesia Republic, 2011. 


\subsection{Data Collection and Analysis Methods}

The researcher employed several sources of evidence in collecting the following case study data, including in-depth interviews, documentation, and direct observation (Creswell 2013). Then it will be analyzed based on theory, with a special case study method to discover the processes and stages of regional development. According to Yin (2009), the analysis techniques are timeseries, logic models, and cross-case synthesis. In time-series analysis, the diachronic method will be carried out to see the development process over a certain period of time (Figure3). The diachronic analysis starts with 1991, when the Borobudur area has been designated a UNESCO World Heritage Site, until 2019, when the research begun. Analysis of the logic model is carried out to identify the cause-and-effect series that occurs and form a particular model, so the periodicity in the series will appear. And cross-case synthesis analysis is used in multiple-case studies, which will compare in depth each case. Thus obtaining the developed stage of the Butler (1980), Miossec (1976), and van Doorn (1979), and then, these stages are contextualized with the results of the analysis that occurred at NSTA Borobudur (Figure 3).

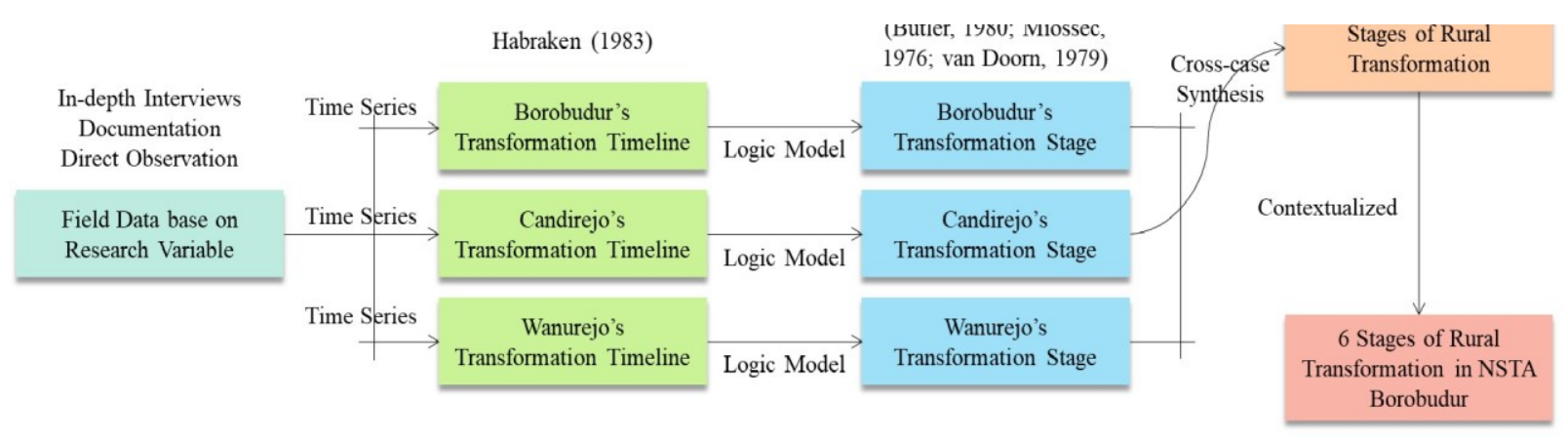

Figure 3. Analysis Process. Source: Computed by Author, 2020.

\section{Results}

\subsection{History of Tourism Development in Borobudur}

\subsubsection{Borobudur as a Tourism Generator}

Tourism activities in the Borobudur area began to be felt in the 1980s, along with the enactment of the area around the temple into one managed by the state government. The restoration and arrangement of the area around the temple were carried out by an institution called the Archaeological Park, which has now been transformed into a Taman Wisata Candi Inc. (TWC), part of the Ministry of State-owned Enterprise. The year 1983 marked the start of tourism activities in Borobudur, with visiting activities in the temple area. This tourism activity has expanded with the demand by the tourists to tour the rural areas around the temple. According to the tourists' explanations in Borobudur, in 1993 a rural-based tourism model was initiated as an alternative tourism offer in Borobudur. This is the result of the registration of the Borobudur Temple in 1991 as a UNESCO World Heritage Site. The development of tourism and the economy in the area becomes exponentially wider (UNESCO 2021).

Since the opening as a tourist area, Borobudur, Mendut, and Pawon temples, with all their potential, have succeeded in attracting a high number of tourists, providing multiple effects to the surrounding villages. Borobudur is not only a source of historical and scientific buildings. Borobudur has also become an economic source for the people around the temple. With all the potential, Borobudur indirectly becomes a valuable driving force for tourism and economic development in the area around Borobudur. 
Table 2. Borobudur and Mendut Pawon Temple Visitor 2019.

\begin{tabular}{|l|l|l|l|}
\hline \multicolumn{2}{|l|}{ Borobudur } & \multicolumn{3}{|l|}{ Mendut Pawon } \\
\hline Domestic & International & Domestic & International \\
\hline $3,747,757$ & 242,082 & 16,926 & 88,570 \\
\hline
\end{tabular}

Source: the Central Bureau of Statistics (BPS) Magelang Regency, 2021

From these extensive tourist visits, encouraging changes in the local socio-economy, this can be indicated by a shift in the livelihoods of the local community to the tourism sector, from being farmers to workers in the Taman Wisata Candi Inc. and traders in the temple area (Biantoro and Ma'rif, 2014; Hamzah, Hermawan, and Wigati, 2018). With this strategic value, in 2011, the Indonesian government, through RIPPARNAS, designated the Borobudur Area as one of the 88 National Strategic Tourism Areas named KSPN Borobudur. This determination was reinforced by a meeting on July 15, 2019 (BPIW, 2020), with the occasion of nomination of Super Priority Tourism Destinations of 5 regions, including Borobudur in Central Java.

\subsubsection{Rural Tourism in Borobudur Area}

The increasing number of tourist visits to Borobudur Temple has contributed to tourism development in the surrounding area. The potential of the villages around Borobudur was also explored, and it gave birth to the tourist villages and other tourist attractions in the surrounding area. According to Kusno (2017), the local community uses the potential distribution of tourists in Borobudur and benefits from the tourism sector. It takes the form of rural development as a tourist attraction by offering a rustic atmosphere and local attractions, such as traditional music, handicrafts, and home industries (Figure 4).

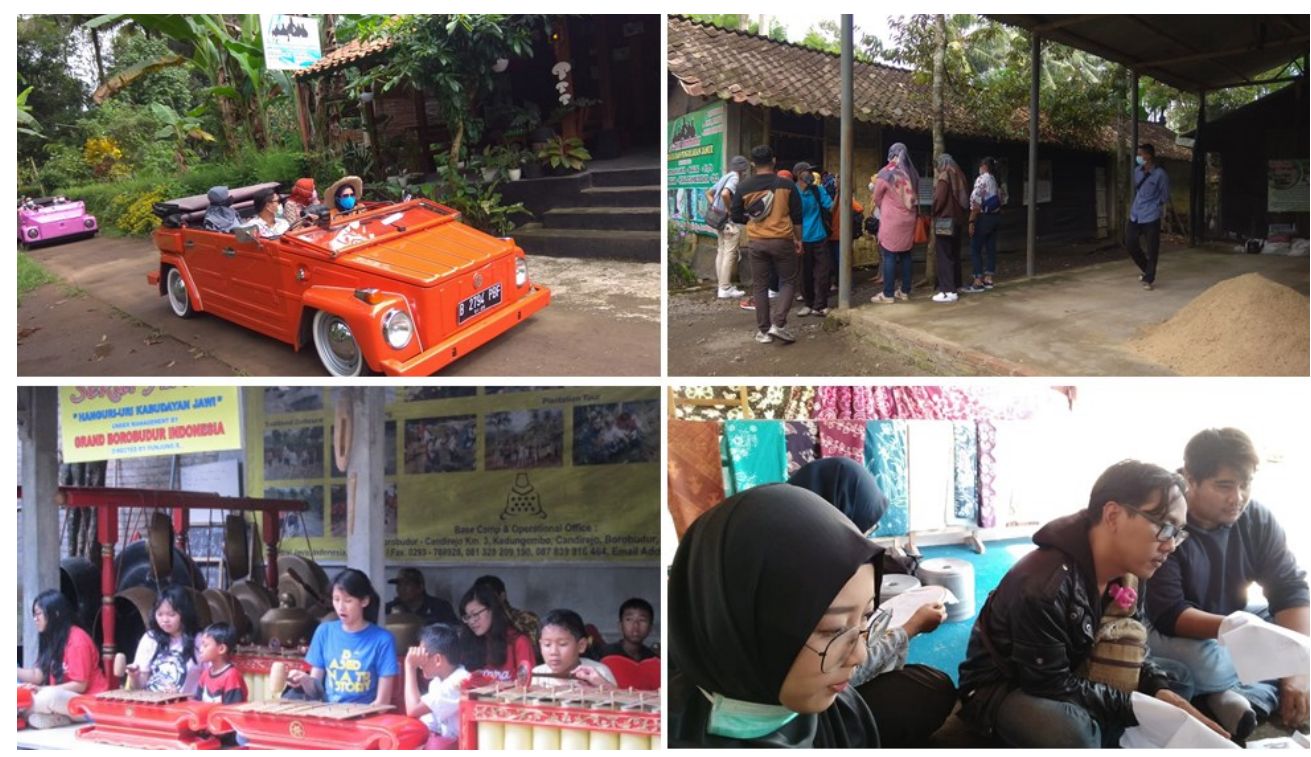

Figure 4. Rural Attraction in Borobudur. Source: Author's Personal Photo Collection, 2019.

The government's policy with the Super Priority Destinations program improves the development of villages around Borobudur, especially with infrastructure development, such as pedestrians, and road paving. In addition, the government issues several policies to support and improve the local economy by developing tourist accommodation facilities, namely Homestay Swadaya. This program directly impacts these villages because it is directly related to houses in the village (Figure 5). 

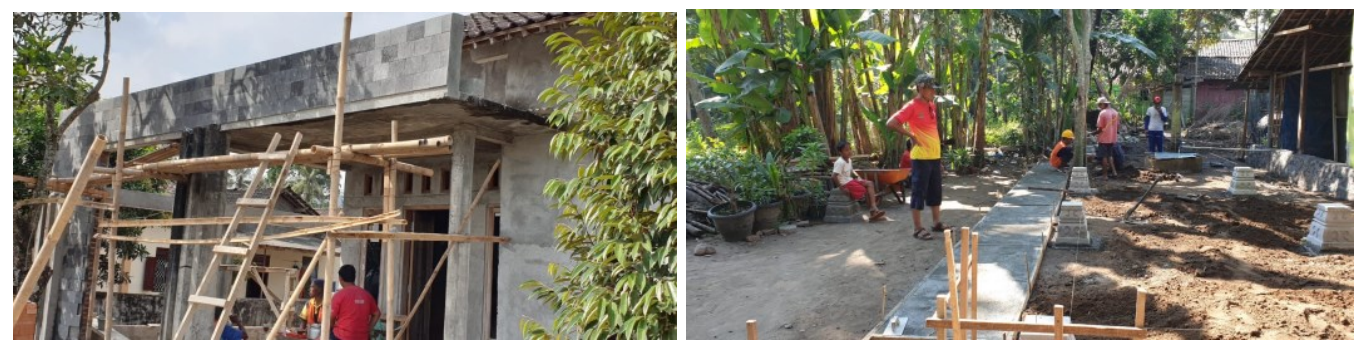

Figure 5. Government Program Homestay Swadaya. Source: Source: Author's Personal Photo Collection, 2019.

\subsection{Timeline of Tourism Development}

\subsubsection{Borobudur Village Tourism Timeline}

Since 1991, 3 villages out of 20 villages in Borobudur District grew rapidly the tourism activities during the development of the Borobudur Temple Area, respectively: Borobudur, Candirejo, and Wanurejo (Figure 6).

Borobudur Temple is the center of tourism activities in the area, being located in Borobudur Village, experienced the greatest and fastest impact among other villages. When other villages were simple settlements, Borobudur Village grew into an alternative tourist destination for the temple, and other rural attractions. But, tourism activities in Borobudur remained still heavily rely on temple tourism, whereas countryside activity provides an alternative tourist activity. The existence of third-party intervention has encouraged the temple to develop into a location for international-scale activities/events, which has contributed to developing the economy around the temple, such as lodging, culinary, souvenirs, or parking businesses. The construction of a paved road network and the Village Economic Center or Balkondes are examples of implemented policies in all Borobudur District villages. In fact, this has encouraged the development of tourism and new accommodation facilities, both network-based hotels, guesthouses, and network-based accommodations.

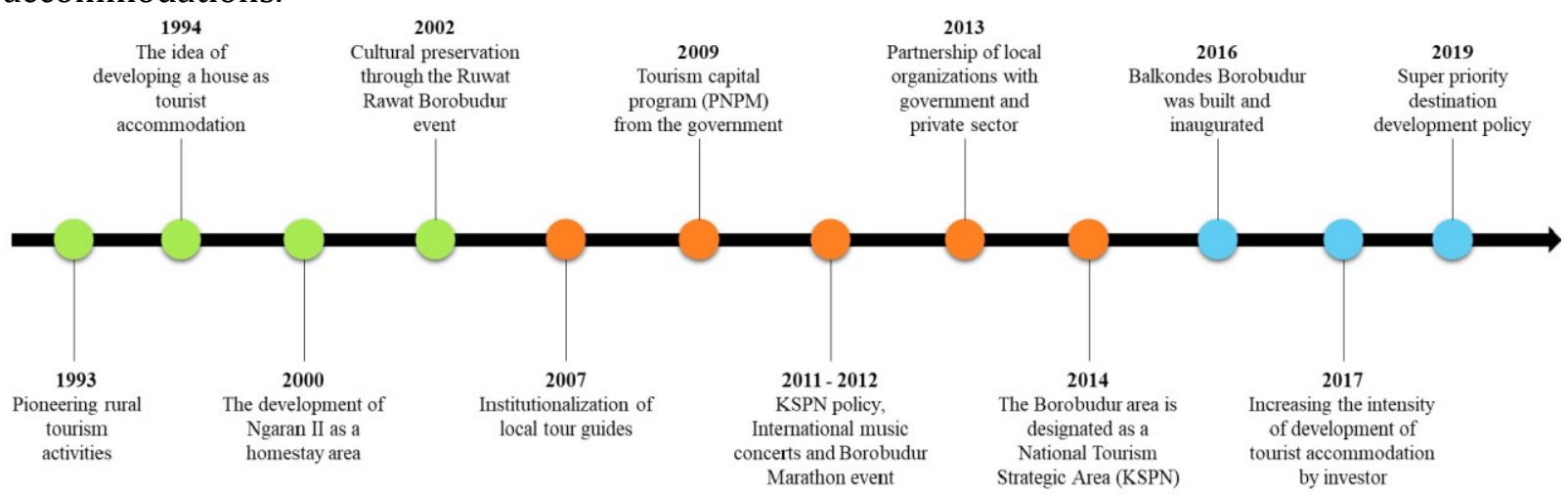

Figure 6. Timeline of Borobudur Village Tourism. Source: Computed by Author, 2020.

\subsubsection{Candirejo Village Tourism Timeline}

Candirejo Village is one of the villages that is close to Borobudur Temple, about $3 \mathrm{~km}$ faraway. Candirejo village began to develop the concept of rural tourism in 1997, at the initiative of the village chief of Candirejo at that time. Candirejo conducts guidance and strengthening of tourism stakeholders to be ready to develop as a tourism village. This preparation took place from 1997 to 2003 (Figure 7). 


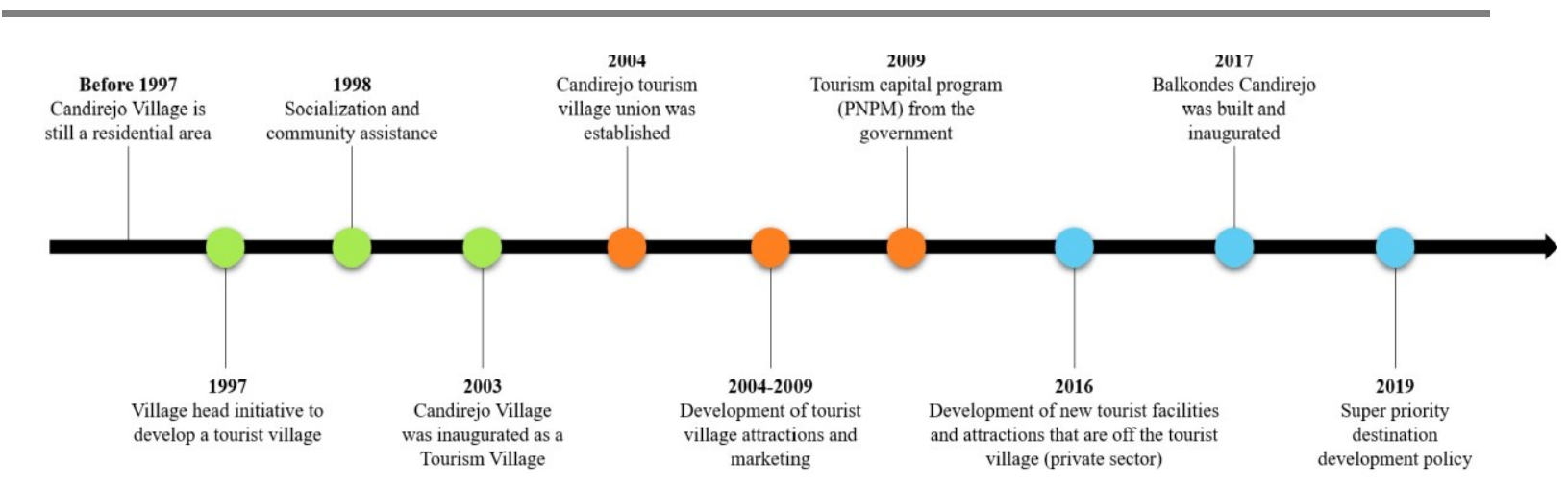

Figure 7. Timeline of Candirejo Village Tourism. Source: Computed by Author, 2020.

Since 2004, the Candirejo Tourism Village has formed a legal institution that directly manages tourism activities in Candirejo called Koperasi Desa Wisata Candirejo. Candirejo is a tourism village Candirejo village has an ecotourism concept by using its original potential through a fully involvement of the villagers' role so that the benefits of tourism will be immediately received and enjoyed by the residents themselves. Government policies, such as Tourism Capital Program or PNPM Pariwisata, Balkondes, and Homestay Swadaya have also been involved in this village. However, to this date, Candirejo has simultaneously developed as a tourism village while maintaining its area's sustainability, as stated by the head of the Candirejo tourism village cooperative in an interview.

\subsubsection{Wanurejo Village Tourism Timeline}

The development of Borobudur Village as a tourist destination has led to rural and natural tourism packages. Besides, the homestay has also developed due to the needs of tourists. This encourages the surrounding villages to participate in developing rural tourism. Wanurejo, directly adjacent to Borobudur, began to create village tour packages when seeing opportunities for tourist to start traveling to the village after visiting the temple.

Tourism activities in Wanurejo founded in 1999, was accompanied by the setting up of an organization, named Paguyuban Karya Muda, which was considered to be the driving force of tourism, as well as the formation of Bapardes (Village Tourism Board) in 2003, Koparda (Regional Tourism Cooperative) in 2013, along with cooperation offers from Bank Negara Indonesia (BNI) as a forerunner in 9 Wanurejo hamlets, Badan Usaha Milik Desa (BUMDES) and then there was Balkondes in 2016 (Figure 8). Today, tourism in Wanurejo Village has been running with its stable management by Bapardes Wanurejo.

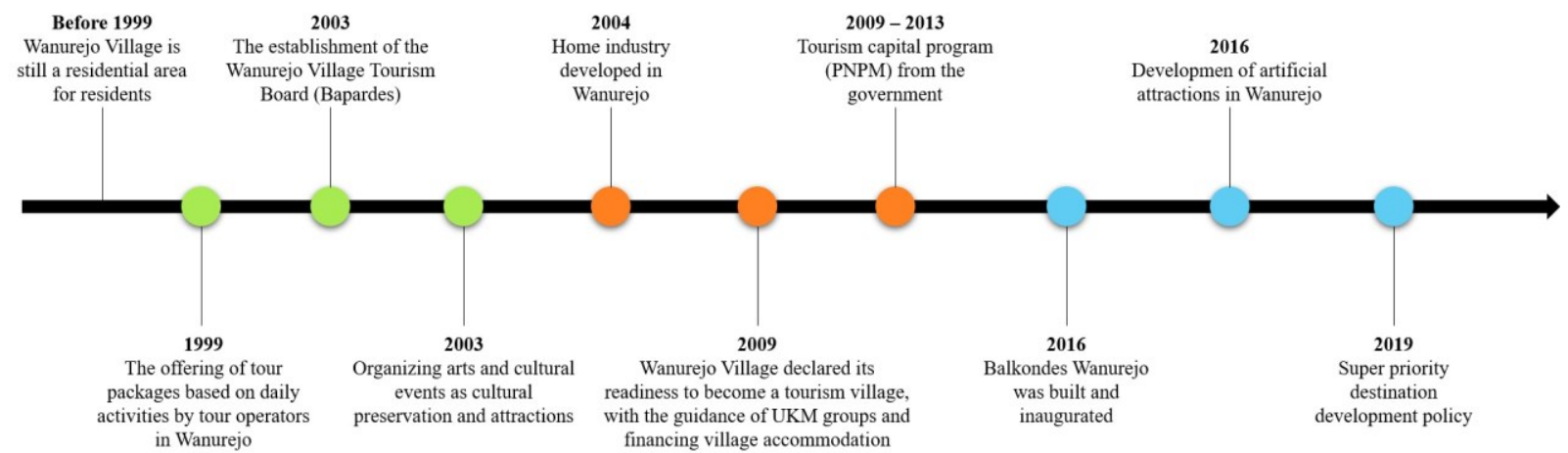

Figure 8. Timeline of Wanurejo Village Tourism. Source: Computed by Author, 2020. 


\subsection{Stages of Transformation}

\subsubsection{Borobudur Village}

The process of the transformation stages from the results of the timeline elaboration in Borobudur Village is below.

Exploration Stage. In 1993 a new idea emerged, developed by tourism activists in Borobudur in response to tourist requests as an alternative to temple tourism. In addition, homestays and facilities in residential areas have begun to grow in order to meet the tourist needs and to increase the villagers' income.

Participation Stage. At this stage, ideas are developed from both the community and the government. Packaging and attraction innovation develop not only sightseeing and rural activities but also cultural performances and events. The government and the private sector also play a role in developing ideas in tourism activities, with policies (physical assistance and business capital) and investment (business development and events) in the tourism sector.

Consolidation and Expansion Stage. The development of Borobudur as a Super priority tourism area has grown rapidly: Infrastructure development, new tourist attractions, and the emergence of tourism businesses from the local villagers to meet the increasing tourist needs. Tourism development in Borobudur Village has experienced a shift. However, it still relies on the rural natural atmosphere and local cultural arts. The pressure-driven motivation from tourists, government, and outsiders (investors) encourages tourism development in Borobudur to be more dynamic, both in a tourist attraction, management, and ownership alongside tourist facilities development.

\subsubsection{Candirejo Village}

In Candirejo Village the process of the transformation stages from the results of the timeline elaboration is described below.

Exploration Stage. Candirejo responded to the development of tourism in the area around the temple; with the initiative of the village chief at that time, the village government began to socialize the idea of developing a tourism village for Candirejo residents. Guidance and strengthening of tourism activists are also carried out as a foundation for developing a tourism village. Finally, in 2003 Candirejo Village was inaugurated as a Tourism Village by the Minister of Tourism and Culture of the Republic of Indonesia.

Participation Stage. Candirejo Tourism Village has strengthened its organization by establishing a cooperative organization. This has developed the management and positioning of tourism villages as ecotourism villages (based on nature and culture). Candirejo is also one of the villages included in the capital policy in the tourism sector.

Consolidation and Expansion Stage. The rapid development of the Borobudur super-priority area has also had an impact on Candirejo. Villages also experience government policies that have implications for the development of tourism infrastructure. Besides of that, the construction of new tourist facilities and attractions also appears, such as Balai Mijil, Omah Pring, and Ndalem Sasono Asri, including supporting facilities built by tourism villages such as Omah Bapa and Ndalem Biyung.

\subsubsection{Wanurejo Village}

The following is the process of the transformation stages from the results of the timeline elaboration in Wanurejo Village 
Exploration Stage. Wanurejo Village responded to temple tourists' widespread village roaming activities as a village directly adjacent to Borobudur Village by initiating tour packages based on daily activities in 1999. The Wanurejo Village Tourism Board, as a tourism management agency in Wanurejo is increasingly supporting tourism development by building and developing tourist destinations in Wanurejo, such as culture and tour packages for people's daily activities.

Participation Stage. One of the leading activities in Wanurejo Village is the Kirab (long march) and Wanurejo Cultural Performance which is the embodiment of Saparan Perti Desa Wanurejo. This activity has been held every year since 2003. Apart from being grateful toward The One Almighty God, this activity is also a promotional media and tourist attraction. This development encouraged the development of a homestay in Jowahan hamlet in 2011, until 2013 received coaching assistance from Public Bank as Kampoeng BNI Wisata Borobudur.

Consolidation and Expansion Stage. The development of the Wanurejo Balkondes encourages the development and improvement of other tourist attractions by the private sector, such as the Junkyard and tourist events (Wanurejo Night Market and the Wanurejo Cultural Performance Festival). Wanurejo's position close to Borobudur encourages Wanurejo to develop as an area that develops attractiveness and facilities to support tourism activities in Borobudur. The development of accommodation facilities in Wanurejo is also relatively rapid, especially holding events in the Borobudur area. Impromptu accommodation appears from residents' homes when the demand for lodging in Borobudur is skyrocketing.

\subsubsection{Synopsis for Bordobudur Destination}

Exploration Stage has the Borobudur Temple as a nucei. Borobudur Village development as a village tourist destination has given the opportunity for locals to provide rural and nature tour packages. Besides that, local inns (homestays) have also increased due to the tourists' demands. This encourages surrounding villages to participate in developing rural tourism. Wanurejo adjacent to Borobudur, began to create village tour packages. The development of tourism activities in the temple area, did not directly influence Candirejo Village, located about $5 \mathrm{~km}$ faraway from the temple. It was their proper initiative to to develop the village as a tourist area. It lasted since 1997 to 2003 (Table 3).

Table 3. Synopsis of Exploration Stage

\begin{tabular}{|l|l|}
\hline Variable & Data \\
\hline $\begin{array}{l}\text { Borobudur temple tourist arrivals (TWC, } \\
2003)\end{array}$ & $\begin{array}{l}\text { Domestic: 2,007,917 } \\
\text { International: 62,776 }\end{array}$ \\
\hline Mendut Pawon temple tourist arrivals (2003) & $\begin{array}{l}\text { Domestic: No Data } \\
\text { International: No Data }\end{array}$ \\
\hline Amenities/ Accommodations & 23 Tourist units \\
\hline Attractions & $\begin{array}{l}\text { 7 Attractions (Borobudur-Borobudur temple; } \\
\text { Candirejo Candirejo village tourism, Tiban } \\
\text { mosque, Banyuasin, Watu Mijil) }\end{array}$ \\
\hline
\end{tabular}

Participation Stage.Tourism activities in Borobudur still heavily rely on temple tourism as the main attraction; rural tourism offers alternative tourism activity. The intervention of a third party encourages the temple to also house activities/events on an international scale. This helps develop the local's economy around the temple, such as lodging, culinary, souvenirs, and parking businesses. This development also impacts Wanurejo, which is growing as a supporting area for Borobudur tourism facilities. In addition, Wanurejo also offers alternative tourist attractions to 
accompany temple tours, such as traditional tourism, arts and culture, rural nature tourism, and village tourism 2003-2004. Candirejo tourism village was inaugurated and then established a cooperative as the sole manager of tourism activities. This further encouraged the development of Candirejo tourism and raised Candirejo as a competitive tourist village. In addition, in 2009, the Indonesian government provided PNPM, not only for Borobudur Village but also for Candirejo and Wanurejo.

Table 4. Synopsis of Participation Stage

\begin{tabular}{|l|l|}
\hline Variable & Data \\
\hline $\begin{array}{l}\text { Borobudur temple tourist } \\
\text { arrivals (TWC, 2014) }\end{array}$ & $\begin{array}{l}\text { Domestic: } 3,157,166(+1.149 .249) \\
\text { International: } 241,814(+179,038)\end{array}$ \\
\hline $\begin{array}{l}\text { Mendut Pawon temple tourist } \\
\text { arrivals (2014) }\end{array}$ & $\begin{array}{l}\text { Domestic: } 994 \\
\text { International: 77,197 }\end{array}$ \\
\hline Amenities/ Accommodations & 38 Tourist units \\
\hline Attractions & $\begin{array}{l}\text { 11 Attractions (+4) } \\
\text { Borobudur: Topeng purba traditional dancing. } \\
\text { Candirejo: Omah Mbudur resort and art. } \\
\text { Wanurejo: House of Batik Lumbini, Elo Progo art house. }\end{array}$ \\
\hline
\end{tabular}

Consolidation and Expansion Stage. Government policies regarding the development of strategic national tourism areas to the tourism super-priority areas in Borobudur have an impact not only on Borobudur Village but also in surrounding villages, including Wanurejo and Candirejo villages. In addition to increasing visits to Borobudur, this policy also impacts infrastructure development and provides opportunities for investors to open tourism businesses in Borobudur.

The construction of a paved road network and Balkondes (Balai Ekonomi Desa/Village Economic Center) is an example of a policy implemented in all villages in the Borobudur District. This even encourages the construction of artificial tourist attractions and new accommodation facilities, such as hotels, guesthouses, and network-based inns. In addition, music concerts, sports, bazaars, and cultural events are also frequently being held in the Borobudur area.

Table 4. Synopsis of Consequence Stage

\begin{tabular}{|c|c|}
\hline Variable & Data \\
\hline $\begin{array}{l}\text { Borobudur temple tourist arrivals } \\
\text { (TWC, 2019) }\end{array}$ & $\begin{array}{l}\text { Domestic: } 3,747,757(+590.591)(\text { Figure 9) } \\
\text { International: } 242,082(+268)\end{array}$ \\
\hline $\begin{array}{l}\text { Mendut Pawon temple tourist arrivals } \\
(2019)\end{array}$ & $\begin{array}{l}\text { Domestic: } 16,926(+15,932) \\
\text { International: } 88,570(+11.373)\end{array}$ \\
\hline Amenities/ Accommodations & 153 Tourist Accommodations (+115) (Figure 10) \\
\hline Attractions & $\begin{array}{l}33 \text { Attractions (+22) } \\
\text { Borobudur: Balkondes Borobudur, Svarga Bhumi, } \\
\text { Clorot home industry, Cetta souvenir shop, BW } \\
\text { Craft. } \\
\text { Candirejo: Balkondes Candirejo, Omah Pring, Mata } \\
\text { Langit, Omah Mijil. } \\
\text { Wanurejo: Balkondes Wanurejo, Junkyard, } \\
\text { Arbetaria, Liadiah Art, Bambu art, House of batik } \\
\text { Dewi Wanu, camping ground, Omah Sanggar, } \\
\text { Limanjawi Art House, Bumaya Sastra Art Gallery, } \\
\text { House of Batik Tingal, Rik Rok wood craf, Cycling. }\end{array}$ \\
\hline
\end{tabular}




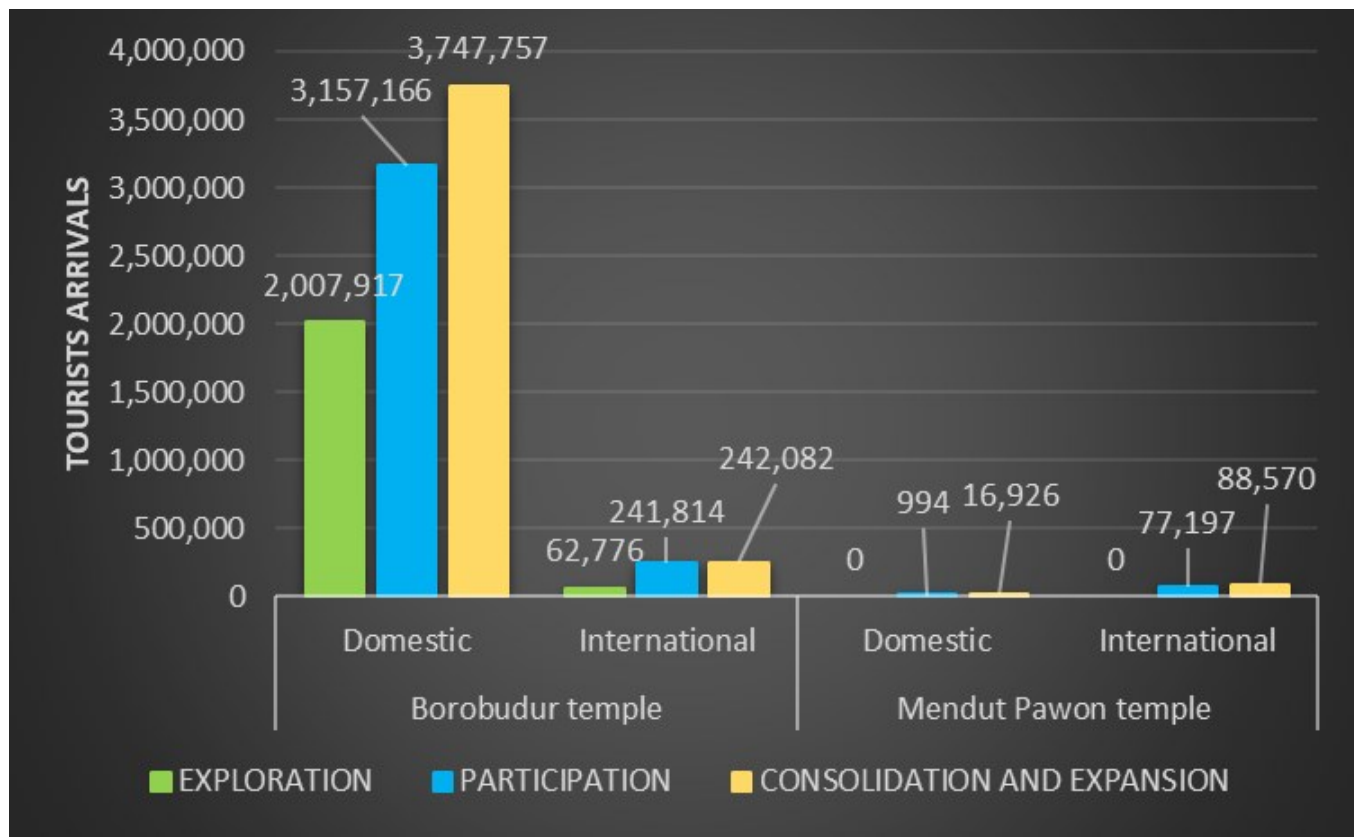

Figure 9. Number of Tourist Arrivals in Borobudur Mendut Pawon Temple in 2019. Source:

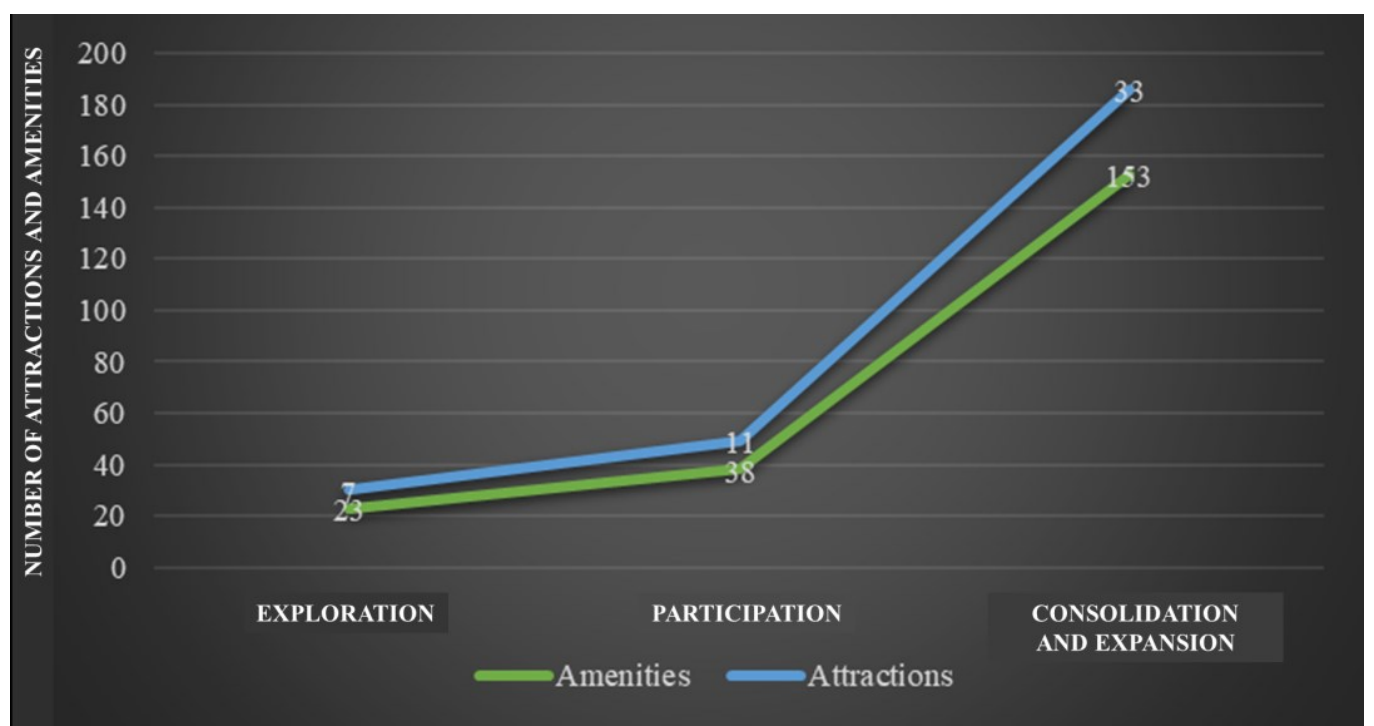

Computed by Author, 2020.

Figure 10. Attractions and Amenities Growth in Borobudur Area in 2019. Source: Computed by Author, 2020.

Thus, from the intial stage, to the final one, the destination was higly developed (Figure 11). 


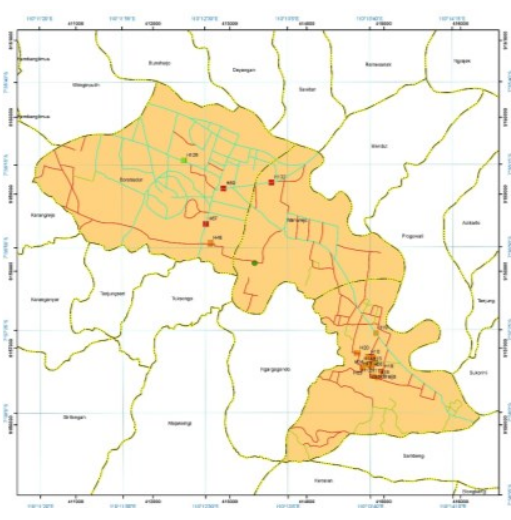

Exploration Stage

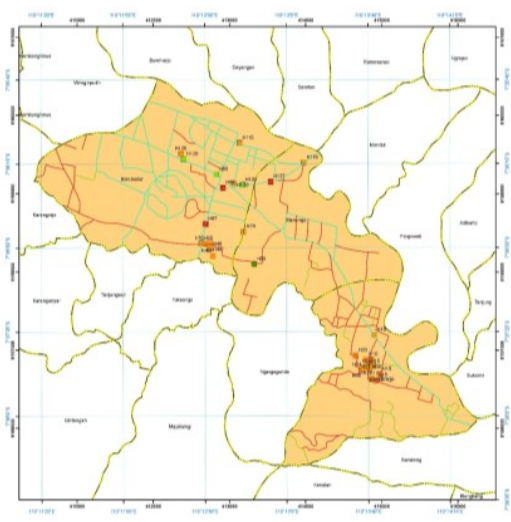

Participation Stage

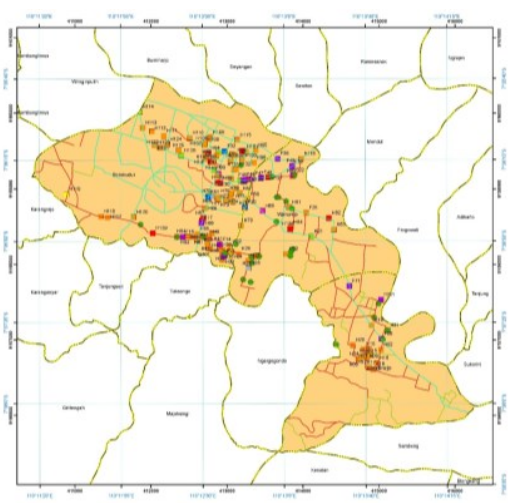

Consolidation and Expansion Stage

Figure 11. The Distribution of Tourism Components. Source: Computed by Author, 2020.

\subsection{Stages of Rural Transformation}

The stages of transformation will be contextualized with the stages of rural transformation in the NSTA of Borobudur, with the following description:

1. Exploration stage (1991 - 2003): The discovery of new ideas for tourism activities is developed and encouraged by initiators from within the village so that the stage of the exploration in the transformation of a tourism village is Initiation. Initiation is defined as a process or preparation that must be carried out in starting a specific activity.

2. Participation stage (2004 - 2014): In the participation stage, communicating and developing tourism activity ideas in question is the development of tourism institutions called Association and the development of attractions or Diversification. Government policies and private involvement in tourism activities have emerged so that this activity of outside interference can be referred to as Intervention.

3. Consolidation and Expansion stage (2015 - now): This stage is a form of causal relationship from the occurrence of tourism activities, which changes the village area due to tourism activities. In this context, these changes result from the development and changes in land use, referred to as Expansion. As well as taking over ownership of land or buildings from local residents to outsiders, or it can be called an Acquisition. 


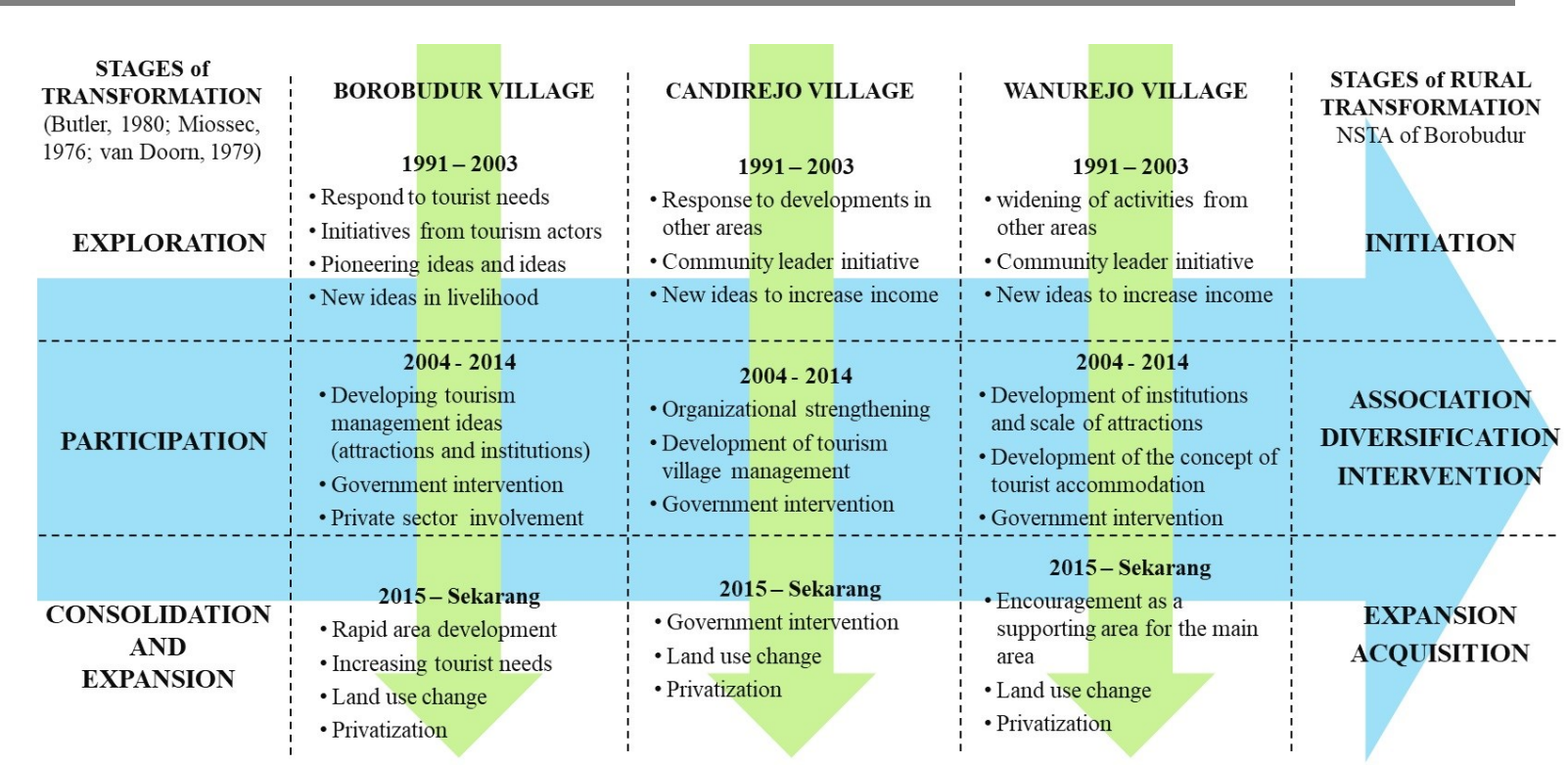

Figure 12. Stages of Rural Transformation. Source: Computed by Author, 2020.

Village transformation is a series of changes in the village due to the development of tourism activities. This change occurs because there is an authority or an effort to produce a new identity. Authority can come from internal factors in the local community or external factors (private parties and especially government policies regarding NSTA). So, it can be concluded that the village transformation process at NSTA of Borobudur goes through 6 stages, including:

1. Initiation stage, which is the preparation process in pioneering a tourism village that is driven by a local movement;

2. Association stage; is a stage of institutionalizing tourism as an organization that manages and develops tourism activities in the village;

3. Diversification stage, a stage where the process of planning development, management, services, attractions packaging, and marketing of tourism activities;

4. Intervention stage, which is the involvement of third parties in the development of tourism activities;

5. Expansion stage, is the expansion of the scope of physical and non-physical tourism activities carried out by tourism business owners, both from inside and outside the area; and

6. Acquisition stage, is a stage where the emergence of activities to take over areas and tourism activities by parties outside the village, as business development.

\section{Conclusion}

According to the analysist of transformation stages from Butler (1980), Miossec (1976), and van Doorn (1979), the tourist village in NSTA Borobudur goes through 3 stages, including exploration, participation, as well as consolidation and expansion. In the exploration stage, the tourist village began to offer nature and culture-based tourism with encouragement from local champions. The next stage is the involvement of local communities with the development of tourism businesses and the formation of institutions. In the last stage, the government's policy regarding the development of a NSTA into a tourism super-priority area in Borobudur has an 
impact on these villages. The biggest impact is infrastructure development and the entry of investors. Based on the results of the transformation stages, contextually the stages of rural tourism transformation in NSTA Borobudur, goes through 6 stages, and those are: (1) Initiation; (2) Associations; (3) Diversification; (4) Intervention; (5) Expansion; and (6) Acquisition.

This research purposes of providing direction for the development of government policies, especially in tourism planning in the NSTA area. At the same time, as a new scientific approach for researchers in tourism, especially about rural tourism and tourism village. As a suggestion for further research, it can be researched on the principles of sustainable tourism development in the development of tourism villages in the future. In addition, it is also possible to examine policies that can be applied to tourist villages in each of the stages described in this study.

\section{Acknowledgments}

We would like to express our gratitude to the Indonesia Endowment Fund for Education (LPDP) Scholarship under the Indonesia-Domestic Lecturer Excellence Scholarship (BUDI-DN) 2017. We also would like to thank The Doctoral Program of Architecture, Gadjah Mada University, for all the assistance that makes this research conductible.

We also thank to local community members, who gave their consent to publish their photos.

\section{References}

1. Ahmed, I., 2017. Role of Adaptive Home-Based Workspaces in Coping Gender Inequality in Korail Slum, Dhaka. Civil Engineering and Architecture, 5(5), p.161-72.

2. Ahmed, I., \& Jahan, N., 2013. Rural Tourism-Prospects in Rustic Bengal. European Journal of Business and Management, 5(16), p. 163-172.

3. Al-Athas, S., 2016. Transformasi Struktur Bentuk Jaringan Jalan Di Kawasan Simpanglima Kota Bandung. NALARs, 15(2), p. 121.

4. Biantoro, R., and Ma'rif, S., 2014. Pengaruh Pariwisata Terhadap Karakteristik Sosial Ekonomi Masyarakat Pada Kawasan Objek Wisata Candi Borobudur Kabupaten Magelang. Teknik PWK (Perencanaan Wilayah Kota) 3(4), p. 1038-47. https://ejournal3.undip.ac.id/index.php/pwk/article/view/6856.

5. Badan Pengembangan Infrastruktur Wilayah (BPIW). Sinergitas Pengembangan Lima Destinasi Pariwisata Super Prioritas. SINERGI. https://bpiw.pu.go.id/uploads/publication/attachment/Buletin\%20BPIW\%20SINERGI\%20Edisi\%204 4\%20-\%20Januari\%202020.pdf. (November 9, 2021)

6. Butler, R. W., 1980. The Concept of a Tourist Area Cycle of Evolution: Implications for Management of Resources. Canadian Geographer / Le Géographe Canadien, 24(1), p.5-12. https://doi.org/10.1111/ j.1541-0064.1980.tb00970.x

7. Creswell, J. W., 2013. Qualitative Inquiry and Research Design: Choosing Among Five Approaches. Thousand Oaks: Sage Publications.

8. Depari, C., 2017. Transformasi Ruang Kampung Kauman Yogyakarta Sebagai Produk Sinkretisme Budaya. Jurnal Arsitektur KOMPOSISI, 10(1), p.11.

9. Dewi, E., 2012. Transformasi Sosial dan Nilai Agama, Jurnal Substantia, 14(1), p.112-21.

10. Groat, L., and Wang, D., 2013. Architectural Research Methods. Second Edi. New Jersey: John Wiley \& Sons. Inc.

11. Habraken, N., 1983. Transformations of The Site. Cambridge, Massachusetts: MIT Press.

12. Hamzah, F., Hermawan, H., and Wigati, W., 2018. Evaluasi Dampak Pariwisata Terhadap Sosial Ekonomi Masyarakat Lokal. Jurnal Pariwisata, 5(3): 195-202. http://ejournal.bsi.ac.id/ejurnal/index.php/jp.

13. Karatosun, M., and Çakar, D., 2017. Effects of Cittaslow Movement on Conservation of Cultural Heritage: Case of Seferihisar \& Halfeti, Turkey. Civil Engineering and Architecture, 5(3), p. 71-82.

14. Kusno, Nur Adi. 2017. Perubahan Nilai Ruang Kawasan Wisata Borobudur. Seminar Nasional Hasil Penelitian Universitas Kanjuruhan Malang 2017, p.97-101. 
15. Miossec, J. M., 1976. Eléments Pour Une Théorie de L'espace Touristique. Tourist Review, 29(4), p. 124131.

16. Moleong, L., 2005. Metodologi Penelitian Kualitatif. Bandung: Remaja Rosdakarya.

17. Najoan, S., and Mandey, J., 2011. Transformasi Sebagai Strategi Desain. Media Matrasain, 8(2), p.11730.

18. Pamungkas, I., and Muktiali, M., 2015. Pengaruh Keberadaan Desa Wisata Karangbanjar Terhadap Perubahan Penggunaan Lahan, Ekonomi Dan Sosial Masyarakat. Teknik Perencanaan Wilayah Kota, 4(3), p. 361-72.

19. Prakoso, A.A., Pradipto, E., and Roychansyah, M.S., 2020. Typology of Tourist Accommodation in the Borobudur Area, Indonesia. International Journal of Innovative Research and Development, 9(8), p. 12228.

20. Prakoso, A.A., Pradipto, E., Roychansyah, M.S., and Nugraha, B. S., 2020. Community-Based Tourism: Concepts, Opportunities and Challenges. Journal of Sustainable Tourism and Entrepreneurship, 2(2), p. 95-107.

21. Sesotyaningtyas, M, Pratiwi, W. D., and Setyono, J., 2015. Transformasi Hunian Dengan Perspektif Spasial Dan Tatanan Budaya: Komparasi Permukiman Kumuh Bang Bua, Thailand Dan Kampung Naga, Indonesia. Geoplanning: Journal of Geomatics and Planning, 2(2), p. 116-23.

22. Setyaningsih, W., 2016. Transformasi Arsitektural Dari Kampung Kota Menjadi Kampung Wisata. Gadjah Mada University.

23. Stabler, M., 1997. Tourism and Sustainability: Principles to Practice. Wellingford: CAB International.

24. Susanti, I., Dewi, N. I. K., and Permana, A. Y., 2018. Tatanan Teritorial Dalam Proses Transformasi Hunian. Jurnal Arsitektur ZONASI, 1(1), p.27. https://ejournal.upi.edu/index.php/jaz/article/ view/11542.

25. UNESCO. 2021. Borobudur Temple Compounds. UNESCO World Heritage List. https://whc.unesco.org/ en/list/592 (May 19, 2021).

26. Vanderstoep, Scott W., and Deirdre D. Johnston., 2009. Research Methods for Everyday Life: Blending Qualitative and Quantitative Approaches. San Francisco: Jossey-Bass.

27. van Doorn, J. W. M., 1979. The Developing Countries: Are They Really Affected by Tourism? Some Critical Notes on Socio-cultural Impact Studies. Leisure Studies and Tourism Seminar.

28. Widyastomo, D., Faqih, M., and Hayati, A., 2015. Setting Transformation and the Meaning of Residence in Sentani's Tribe Tradition. Humanities and Social Sciences 3(1), p. 37.

29. Xi, J., Wang, X., Kong, Q., and Zhang, N., 2015. Spatial Morphology Evolution of Rural Settlements Induced by Tourism: A Comparative Study of Three Villages in Yesanpo Tourism Area, China.Journal of Geographical Sciences 25(4), p.497-511.

30. Yin, R.K., 2009. Case Study Research: Design and Methods. Fourth Edi. Los Angeles: Sage Publications.

(C) 2021 by the authors. Submitted for possible open access publication under the terms and conditions of the Creative Commons AttributionNonCommercial-No Derivatives (CC BY NC ND) 4.0 International License. (https://creativecommons.org/licenses/by-nc-nd/4.0/). 